\title{
Studentovo hodnocení výuky: validace a adaptace dotazníku CEQ pro podmínky českých vysokých škol
}

\author{
Kateřina Juklová a, Stanislav Michek ${ }^{a}$, Petr Soukup ${ }^{\text {b }}$, Jindra \\ Vondroušová ${ }^{a}$, Daniela Vrabcová ${ }^{\mathrm{a}}$ \\ ${ }^{\text {a } U n i v e r z i t a ~ H r a d e c ~ K r a ́ l o v e ́, ~ P e d a g o g i c k a ́ ~ f a k u l t a ~}$

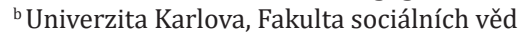

Redakci zasláno 6. 4. 2018 / upravená verze obdržena 14. 6. 2020 /

k uveřejnění přijato 14. 6. 2020

\begin{abstract}
Abstrakt: Cílem př́íspěvku je seznámit s průběhem a výsledky validace a adaptace dotazníku CEQ (Course Experience Questionnaire) a diskutovat jeho využitelnost v aktuálních podmínkách českých vysokých škol. Originální verze dotazníku vznikla na základě intenzivních výzkumů učení studentů koncem 80. let v Austrálii a v současné době je jedním z celosvětově nejužívanějších nástrojů pro hodnocení kvality výuky studentem v terciárním vzdělávání. Vzhledem k aktuální potřebě českých vysokých škol realizovat autoevaluační procesy s použitím validních a spolehlivých nástrojů považujeme ověření psychometrických vlastností dotazníku a jeho adaptaci za jedno z možných řešení. $V$ úvodní části textu je nastíněn kontext a okolnosti vzniku australského originálu včetně teoretických koncepcí, které se staly jeho základem. Proces adaptace a validace byl realizován na Pedagogické fakultě Univerzity Hradec Králové (PdF UHK) a proběhl ve dvou fázích kombinujících kvalitativní a kvantitativní př́ístup. V prvním kroku proběhla ohnisková skupina se studenty s cílem ověřit soulad mezi pojetím kvality výuky u českých studentů a zaměřením dotazníku. Následně byl přeložený dotazník administrován 661 studentům učitelství z PdF UHK a ověřován z hlediska konstruktové a kriteriální validity a reliability. Analýzy potvrdily originální pětifaktorovou strukturu dotazníku a uspokojivou vnitřní konzistenci všech škál. Výsledky jsou diskutovány a vztaženy ke zjištění zahraničních autorů i ke kontextu příležitostí a omezení pro používání v českém prostředí. $V$ závěru je upozorněno na limity studie a jsou naznačeny další možné směry úprav.
\end{abstract}

Klíčová slova: CEQ, dotazník, student, kvalita výuky, evaluace výuky

V souvislosti s povinností dokládat zajišt'ování kvality vzdělávací činnosti jsou české vysokoškolské instituce na základě podmínek Národního akreditačního ústavu České republiky aktuálně podněcovány k hledání indikátorů a nástrojů, které budou validní a spolehlivou součástí jejich vnitřních systémů zajišttování kvality. Ty stávající jsou na českých vysokých školách 
přezkoumávány z hlediska funkcí, které mají na základě nových podmínek v rámci instituce plnit, i z hlediska své platnosti a spolehlivosti. Jednou z potíźí, kterým mohou v tomto procesu instituce čelit, je skutečnost, že velká část těchto nástrojů nemá vyjasněná teoretická východiska, a sleduje tak množství různě kompatibilních indikátorů, které svou povahou komplikují interpretaci a využitelnost získaných dat.

O podobném stavu v zahraničí informují autoři několika přehledových studií. Teoretická východiska jsou reflektována většinou pouze v národních šetřeních (Richardson, 2005) ${ }^{1}$. Spooren, Brockx a Mortlemans (2013) ve svém systematickém přehledu analyzujícím 160 empirických studií o studentských evaluacích vysokoškolské výuky publikovaných od roku 2000 na celém světě konstatují, že pouze tři z prezentovaných použitých nástrojů se opírají o teoretická východiska. ${ }^{2}$

Vzhledem ke skutečnosti, že nástroje dosud využívané pro hodnocení vysokoškolské výuky studenty v podmínkách českých vysokých škol jsou obvykle dotazníky a škály vlastní konstrukce a existence teoreticky zdůvodněného a psychometricky ověřeného nástroje použitelného pro hodnocení výuky studentem vysoké školy nám není známa, jedním z možných řešení je adaptace zahraničního instrumentu. Za tímto účelem jsme se zaměřili na dotazník CEQ (Course Experience Questionnaire), jehož teoretická východiska čerpají z tzv. teorie studentova učení (SLT; Gaff, Crombag, \& Chang, 1976; Ramsden, 1979). Kontext vzniku nástroje, vývoj jeho verzí, účely využívání i způsoby práce $\mathrm{s}$ daty byly podrobně popsány $\mathrm{v}$ přehledové studii, která tomuto př́íspěvku předchází (Juklová et al., 2019). Podstatnými součástmi zjištění je skutečnost, že dotazník má spolu s teoretickými základy vysoce uspokojivé psychometrické vlastnosti, pro které byl úspěšně adaptován k využití ve vysokém školství v mnoha dalších zemích světa. Současně existují doklady

1 Richardson (2005) zmiňuje tři odlišné teoretické koncepty zohledňované v rámci národních studentských nebo absolventských šetření. Koncept angažovanosti (student engagement) používaný $\mathrm{v}$ rámci národního šetření $\mathrm{v}$ USA vychází z předpokladu, že kvalita učebních výsledků odpovídá způsobu, jakým se studenti angažují ve vysokoškolském vzdělávání (Kuh, 2009). Hodnocení studentovy spokojenosti je dalším konceptem využívaným v anglofonních zemích, jehož východiskem je podobnost s teorií zákazníka (Harvey \& Kamvounias, 2008). Třetím konceptem vzniklým v australském vysokém školství a později celosvětově rozšíŕeným je studentovo vnímání výukového kontextu, které je součástí tzv. teorie studentova učení (Gaff, Crombag, \& Chang, 1976; Ramsden, 1979).

2 Společně s dotazníkem CEQ (Ramsden, 1991) se jedná o dotazník IDEA (Cashin \& Perrin, 1978) a SEEQ (Marsh, 1982). 
o jeho formách a modifikacích využívaných jako indikátory kvality výuky pro hodnocení na úrovni různě rozsáhlých celků i o zkušenostech týkajících se způsobů integrování zpětné vazby získané dotazníkem do vnitřních systémů zajišt'ování kvality vysokoškolské výuky. Tato zjištění podpořila náš záměr ověřit a adaptovat dotazník CEQ pro použití k evaluaci studentské výuky v prostředí českých vysokých škol.

\section{Cíl studie}

Cílem této studie je informovat o průběhu a výsledcích analýz realizovaných v souvislosti s ověřováním psychometrických vlastností dotazníku CEQ v českém vysokoškolském prostředí a $\mathrm{v}$ návaznosti na tyto výsledky diskutovat možnosti a meze využitelnosti nástroje jako součásti hodnocení kvality vysoké školy v aktuálních podmínkách českých vysokých škol. V rámci tohoto procesu byla provedena deskriptivní analýza jednotlivých položek, ověření konstruktové a kriteriální validity dotazníkového modelu a reliability jeho škál. Součástí analýz bylo dále testování hierarchických modelů s faktory druhého řádu, které pomohlo objasnit odpověd' na otázku, zda ze skórů jednotlivých škál lze součtem utvořit jediné celkového skóre.

\section{Dotazník a jeho vývoj}

\subsection{Teoretický základ a vývoj verzí}

Dotazník CEQ měří konstrukt označovaný jako studentovo vnímání (výukového) kontextu, který je potvrzeným prediktorem studijních procesů a výsledků (Säljö, 1979; Ramsden \& Entwistle, 1981; Trigwell \& Prosser, 1991a; Trigwell \& Prosser, 1991b; Trigwell \& Prosser, 1996; Lizzio, Wilson, \& Simmons, 2002). V rámci teorie studentova učení (SLT) jsou rozlišovány různé typy studijních strategií (procesy) vedoucí k odlišným studijním výsledkům. Tyto jsou označovány jako tzv. studentovy př́stupy k učení (student approaches to learning). Kvalitní učení je konceptualizováno jako tzv. hloubkový př́stup k učení (deep learning) a vyznačuje se záměrem učivu porozumět a zapojováním strategií jako je aktivní analyzování konceptů nebo vysoká úroveň elaborace učiva. Oproti němu tzv. povrchový př́stup k učení (surface learning) charakteristický úsilím dosáhnout cílů s minimem vynaložené energie za užívání rutinních strategií jako např. nereflektované memorizace nebo doslovného opakování učiva s žádoucími výsledky učení nekoreluje (Marton \& Pang, 2006; 
Ramsden \& Entwistle, 1981; Entwistle \& Ramsden, 1983; Biggs, 1989). Výuka vnímaná studentem jako kvalitní ve smyslu konkrétních indikátorů (podrobněji v oddíle 2.2) vede k zapojování hloubkového přístupu k učení a k žádoucím studijním výsledkům (Ramsden \& Entwistle, 1981; Trigwell \& Prosser, 1991b; Trigwell \& Prosser, 1996).

Studentovo vnímání výukového kontextu měřené dotazníkem není informací o vyučovací realitě samotné, ale vypovídá o vnímané studijní zkušenosti dotázaných studentů v určitém čase. Percepce výuky studenty zároveň souvisí se způsoby, jakými studenti reprezentují procesy učení, tzv. koncepcemi učení (např. Säljö, 1979; Beaty, Dall'Alba, \& Marton, 1997; Landbeck \& Mugler, 1994; van Rossum \& Taylor, 1987), které mají vývojový trend a vztahují se k epistemickému a intelektuálnímu vývoji (Perry, 1970; van Rossum \& Taylor, 1987). Tyto vzájemné souvislosti naznačují, že kontext výuky, který je studenty vnímán a hodnocen jako kvalitní a vede k využívání hloubkových studijních strategií i k žádoucím studijním výsledkům, respektuje jejich osobní a vývojové charakteristiky, jako je úroveň dosavadních znalostí, motivace nebo autoregulace (Juklová, 2019).

Dotazník CEQ vznikl sloučením škál několika svých předchůdců․ Jeho první verze čítala 80 položek a později byl počet škál i jejich položek různě krácen. Verze CEQ30 použitá ve zkušebním národním šetření zahrnovala již jen pět z devíti původních škál, z nichž tři korelují s hloubkovými přístupy k učení (Dobrá výuka, Jasné cíle a standardy a Důraz na nezávislost), zatímco dvě zbývající s př́stupy povrchovými (Přiměřená zátěž a Přiměřené hodnocení). Těchto pět škál bylo doplněno jedinou samostatnou položkou dotazující se na celkovou spokojenost studenta s výukou, která byla použita $\mathrm{k}$ jejich validaci. Ověřením dotazníku na souboru více než 4000 studentů posledního ročníku 13 australských vysokoškolských institucí byly potvrzeny jeho psychometrické vlastnosti a dotazník byl označen za spolehlivý a validní nástroj k měření globální studentské zkušenosti (Ramsden, 1991). Od té doby se v různých modifikacích stal součástí každoročního šetření čerstvých absolventů na národní úrovni v Austrálii (Graduate Destination Survey).

3 Konkrétně byla první, 80položková verze dotazníku CEQ sestavena z 25 položek dotazníku Course Perceptions Questionnaire (CPQ; Ramsden, 1983), z pěti položek dotazníku School Experiences Questionnaire (SEQ; Ramsden, Martin, \& Bowden, 1989) a z šesti položek dotazníku Experiences of Studying and Higher Education (ESHE; Entwistle \& Tait, 1990). Ostatní položky byly odvozeny z rozhovorů se studenty širokého spektra vysokoškolských oborů (Elphinstone, 1990). 
V následujících letech podstoupil dotazník více dalších úprav v reakci na nové záměry a priority ve vzdělávací politice i na způsoby jejich testování (podrobně viz Juklová et al., 2019). Například doplněním původní verze CEQ30 o škálu Obecné dovednosti vznikla verze CEQ36 zohledňující potřebu zjišt'ovat u absolventů okruh získaných přenositelných obecných dovedností pro uplatnění v dynamicky se rozvíjející společnosti (Ainley \& Long, 1994). Vynechání škály Důraz na nezávislost z verze CEQ36 spolu s vypuštěním některých položek dalo dále vznik jedné z nejvyužívanějších verzí, CEQ23. $\mathrm{V}$ roce 2001 bylo naopak vyvinuto pět nových škál (Podpora studenta, Studijní zdroje, Kvality absolventa, Učební komunita a Intelektuální motivace), které společně se stávajícími utvořily verzi CEQ50 pokrývající šířeji koncipovanou vnímanou kvalitu výuky, která doplňuje původní pojetí informacemi o percepci podpůrných zařízení a služeb instituce a kvality utvářených podpůrných vztahů (McInnis et al., 2001; Griffin et al., 2003).

Později začal být dotazník využíván na několika různých úrovních měření. Verze CEQ30, CEQ36 a CEQ23 a jejich další modifikace zjištujující globální studijní zkušenosti čerstvých absolventů jsou využívány jako indikátory akademického výkonu institucí pro řízení vzdělávací politiky (Ainley \& Long, 1994). SCEQ (Student Course Experience Questionnaire) ${ }^{4}$ měří globální zkušenost studentů za jeden akademický rok, a je tak indikátorem kvality výuky studijních programů pro potřeby vlastního rozvoje instituce (Trigwell \& Ashwin, 2003; Ginns, Prosser, \& Barrie, 2007). Vznikla i verze měřící percepci výuky studenty jednoho předmětu nebo pedagoga používaná jako indikátor kvality výuky pro potřeby učitelova vlastního rozvoje, USE (Unit of Study Evaluation; Ginns \& Barrie, 2004) ${ }^{5}$, jejíž výsledky je možné za určitých podmínek agregovat na úroveň globální studentské zkušenosti měřené SCEQ. Výhodou současného používání všech těchto dotazníků v rámci jedné instituce jsou široké a jasně interpretovatelné informace jednak o kvalitě vzdělávací činnosti v porovnání s ostatními srovnatelnými institucemi a dále každoroční, resp. semestrální zpětná vazba jednotlivým oddělením

4 Verze, kterou publikovali Ginns, Prosser a Barrie (2007) obsahuje celkem šest škál a 29 položek, přičemž vznikla připojením nové škály Studijní komunita k CEQ23. Dalším rozdílem oproti dotazníku CEQ je, že její položky jsou formulovány v př́tomném čase.

5 Tento dotazník vychází ze čtyř škál dotazníku SCEQ (Dobrá výuka, Jasné cíle a standardy, Přiměřená zátěž a Přiměřené hodnocení), z nichž využívá pouze jedinou, tzv. definující položku, která nejsilněji koreluje s př́śslušnou škálou dotazníku. Položka ze škály Obecné dovednosti je nahrazena naopak více položkami odsouhlasenými radou každého oboru v souladu s jeho cíli (Ginns \& Barrie, 2004). 
i vyučujícím, která umožňuje rychle a cíleně reagovat ve směru zkvalitňování výuky (Ginns \& Barrie, 2004). Plná verze CEQ je zároveň dodnes využívána $\mathrm{k}$ výzkumným účelům, typicky pro ověřování změn ve vnímané kvalitě výuky v souvislosti s implementováním pedagogických inovací na úrovni studijních programů i jednotlivých předmětů (např́klad Lyon \& Hendry, 2002; Steele, West, \& Simeon, 2003; Price, Richardson, \& Jelfs, 2007; Bell, Galilea, \& Tolouei, 2010; Sorensen, 2013; Liu, John, \& Courtier, 2017).

\subsection{Verze použitá k adaptaci}

Pro testování byla zvolena verze dotazníku, která svou strukturou odpovídá CEQ23. CEQ23 je jednou z nejkratších verzí, přesto s vysoce uspokojivými psychometrickými vlastnostmi, což plně vyhovuje záměru využívat jej k autoevaluaci na úrovni jednoho předmětu, kdy je vedle spolehlivosti nástroje nutné zohlednit i jeho délku. To, čím se od originálního CEQ23 námi testovaný instrument liší, je, kromě jazyka dotazníku, absence výrazu „učitelský sbor“, který byl v položkách nahrazen výrazem „vyučující", a odkazů na „studium“, které byly změněny na „předmět“ tak, aby odpovídaly zkušenosti studentů v jediném předmětu. Součástí této verze jsou škály:

- Dobrá výuka (6 položek), vyjadřující studentovo vnímání kvality učitelova výkladu a učitelova zájmu o to, jak si student vede (např. „Vyučující uměl látku dobře vysvětlit") a korelující s hloubkovým př́stupem k učení;

- Jasné cíle a standardy (4 položky), vystihující míru vnímané jasnosti a srozumitelnosti v tom, co se student učí a co se od něho očekává (např. „Standard toho, co se od studentů v předmětu očekávalo, byl dobře známý") a korelující s hloubkovým př́ístupem k učení;

- Přriměřené hodnocení (3 položky), operacionalizované v protikladu k hodnocení mapujícímu porozumění, zahrnující formativní zpětnou vazbu studentovi (např̀ „Vyučující se zajímal/a více o testování toho, co jsem si zapamatoval/a, než toho, co jsem pochopil/a") a korelující s povrchovým př́stupem k učení;

- Přiměřená zátěž (4 položky), popisující míru pocitovaného tlaku na studenta (např. „V předmětu jsem byl/a jako student/ka pod velkým tlakem") a korelující s povrchovým přístupem k učení;

- Obecné dovednosti (6 položek), vyjádřené získanými obecnými dovednostmi pomáhajícími studentům efektivně aplikovat získané předmětové 
dovednosti v pracovním prostředí (např. „Díky předmětu se cítím jistější při řešení neznámých problémů") a korelující s hloubkovým přístupem k učení a Dobrou výukou.

K těmto dimenzím byla po vzoru původní verze CEQ30 dále připojena položka vyjadřující celkovou spokojenost studenta s výukou, která posloužila $\mathrm{k}$ validaci hodnocení ve výše uvedených oblastech („Celkově jsem s výukou předmětu spokojen/a“).

\section{Data, jejich sběr a analýzy}

\subsection{Datový soubor a proces sběru dat}

K prvotnímu ověření psychometrických vlastností dotazníku CEQ pro použití v českém vysokém školství bylo zvoleno prostředí jedné instituce, konkrétně Pedagogické fakulty Univerzity Hradec Králové. V souladu se záměrem instituce ověřit platnost a spolehlivost nástroje a současně generovat zpětnou vazbu vyučujícím a jejich nadřízeným byl umožněn sběr dat od studentů předmětů všech učitelských oborů včetně společného pedagogického základu. Autor originální verze dotazníku byl nejprve kontaktován se žádostí o svolení k využití pro výzkumné a evaluační účely. ${ }^{6}$ Po získání svolení byl dotazník přeložen z originálu do českého jazyka, následně jiným překladatelem zpět do angličtiny a překlad byl porovnán s originálem. $V$ další fázi v červnu 2016 proběhla ohnisková skupina s cílem ověřit pojetí kvalitní výuky v dotazníku s pojetím studentů. Účastnilo se jí osm studentů různých oborů a ročníků Pedagogické fakulty Univerzity Hradec Králové a dva výzkumníci, kteř́ diskusi facilitovali. Ze skupinové diskuse vyplynulo, že znění některých položek v překladu nebylo pro studenty zcela srozumitelné. Podněty, které se opakovaly, byly do přeloženého dotazníku zapracovány. Typicky se jednalo o zjednodušení větné konstrukce položky při maximální snaze o zachování jejího významu. Předložená baterie sestávající z 24 tvrzení dotazníku, na které studenti odpovídali na 5bodové Likertově škále ${ }^{7}$ (viz CEQ23 + 1 položka celkové spokojenosti s výukou), doplňkově položených šesti vybraných

6 K oslovení autora dotazníku došlo v květnu 2015. Na naši žádost byla obratem autorem zaslána znění více dotazníkových verzí.

7 Likertova škála vyjadřovala frekvenci výskytu od nikdy (1), téměř nikdy (2), jak kdy (3), téměř vždycky (4) po vždycky (5) 
otázek z širší verze CEQ $50^{8}$ a dvou otevřených položek ${ }^{9}$ byla následně ve formě tužka-papír administrována 661 studentům různých aprobací a ročníků učitelství. K administraci došlo přímou návštěvou asistentů výzkumníků v průběhu prvního týdne letního semestru 2016/2017 ve výuce, kdy byli studenti požádáni o anonymní hodnocení výuky jednoho předem určeného předmětu ze zimního semestru. ${ }^{10}$ Po vyplnění dotazníku se administrátoři ptali na srozumitelnost položek $v$ dotazníku a žádali respondenty o jakoukoliv zpětnou vazbu k dotazníku.

Způsob realizace těchto evaluací byl oproti předchozím zvyklostem nový ve smyslu užití formy tužka-papír. ${ }^{11}$ Vzhledem $\mathrm{k}$ výše popsanému postupu byla návratnost papírových dotazníků stoprocentní a po podrobné kontrole jich bylo pro neúplnost 14 vyloučeno. ${ }^{12}$ Výsledný datový soubor čítal 647 studentů, z čehož 531 (82,1 \%) bylo žen a 116 (11,9\%) mužů. Hodnoceno bylo celkem 42 předmětů a 44 vyučujících ze 14 kateder/ústavů Pedagogické fakulty Univerzity Hradec Králové. Průměrný věk studentů byl 21,8 let, procentuální zastoupení hodnotících studentů v ročnících bylo: $26,8 \%$ v prvním, $55,5 \%$ ve druhém, $11,7 \%$ ve třetím, $2,6 \%$ ve čtvrtém a $3,4 \%$ v pátém. Mezi hodnocenými pedagogy bylo 28 žen a 16 mužů.

\subsection{Metody analýzy dat}

Data získaná přeloženým dotazníkem CEQ byla zpracována v programu SPSS (verze IBM SPSS Statistics 22 a SPSS AMOS 21). Nejprve byla provedena položková analýza, pro ověření struktury dotazníku byla použita konfirmační analýza, vnitřní konzistence indexů byla následně testována výpočtem koeficientu Cronbachova alfa. Kriteriální validita byla ověřována výpočtem

8 Jednalo se o šest položek, které nejvíce korelovaly na rozšiřujících škálách verze CEQ50 (viz př́loha). Tyto byly zařazeny z evaluačních důvodů a nebyly součástí ověřované struktury.

9 Znění dvou otevřených otázek: „Které aspekty předmětu nejvíce přispívaly k jeho kvalitě?“ „Které aspekty předmětu by potřebovaly nejvíce zlepšit?"

10 Hodnocené předměty (a pedagogové) byly nominovány vedoucími kateder jako předměty zásadní pro jejich obor. Vzhledem k tomu, že studenti učitelství typicky studují dva obory a všeobecný pedagogicko-psychologický základ, maximální počet hodnocení od jednoho studenta byl tři.

11 V letech 2013-2015 byl využíván dotazník vycházející z kompetenčního modelu profesního standardu učitele (Michek \& Maněnová, 2016) administrovaný prostřednictvím online prostř̌edí umožňujícího hodnocení studenty. Později bylo prostředí změněno na systém STAG, který přinesl nutnost přihlášení se.

12 Osloveni však byli pouze studenti př́tomní v prvním týdnu v semestru ve výuce, což celkově ze všech studentů vybraných ročníků a oborů ve studijní evidenci představovalo podíl $65 \%$. 
Pearsonova korelačního koeficientu mezi položkou celkové spokojenosti s výukou a jednotlivými škálami dotazníku. Vzájemné vztahy mezi škálami byly analyzovány rovněž výpočtem Personova korelačního koeficientu.

\section{$4 \quad$ Výsledky}

\subsection{Položková analýza}

Tabulka 1 prezentuje výsledky položkové analýzy, která zjišt’ovala popularitu a rozlišovací schopnost položek. Popularita je vyjádřena hodnotou aritmetického průměru (a. p.), kdy vyšší hodnoty znamenají příznivější hodnocení oblasti. ${ }^{13}$ Rozlišovací schopnost položek naznačují hodnoty směrodatné odchylky (s. o.). Nejhůře rozlišující položkou bylo tvrzení č. 25: „Požadavky na studenty byly vyučujícím stanoveny od začátku semestru“. Hodnota směrodatné odchylky (s. o.) byla nízká $(0,88)$, a. p. na škále $1-5$ byl 4,6 a nejčastěji využívanou odpovědí na škále byla hodnota 5 (vždy). ${ }^{14}$

\section{Tabulka 1}

Položková analýza CEQ23

\begin{tabular}{llcc}
\hline č. p. & Dobrá výuka (DV) & a. p. & s. o. \\
\hline 3 & $\begin{array}{l}\text { Vyučující mi poskytoval/a užitečnou zpětnou vazbu o tom, jak jsem si } \\
\text { v předmětu vedl/a. }\end{array}$ & 3,53 & 1,20 \\
\hline 8 & $\begin{array}{l}\text { Vyučujíć́ mě v předmětu motivoval/a k tomu, abych odvedl/a co } \\
\text { nejlepší práci. }\end{array}$ & 3,64 & 1,11 \\
\hline 16 & Vyučující se snažil/a pochopit moje obtíže spojené s prací v předmětu. & 3,69 & 1,16 \\
\hline 21 & Vyučující se snažil/a, aby jeho/její předmět byl zajímavě podaný. & 3,98 & 1,11 \\
\hline 19 & Vyučující uměl/a látku dobře vysvětlit. & 4,20 & 1,07 \\
\hline 27 & Vyučující věnoval/a dostatek času komentování mé práce. & 3,54 & 1,21 \\
\hline & Jasné cíle a standardy (C) & a. p. & s. o. \\
\hline 6 & $\begin{array}{l}\text { Měl/a jsem jasnou představu o tom, kam směřuji a co se ode mě } \\
\text { v předmětu očekává. }\end{array}$ & 4,00 & 1,06 \\
\hline 12 & $\begin{array}{l}\text { Standard toho, co se od studentů v předmětu očekávalo, byl dobře } \\
\text { známý. }\end{array}$ & 4,16 & 1,03 \\
\hline 25 & $\begin{array}{l}\text { Požadavky na studenty byly vyučujícím stanoveny od začátku } \\
\text { semestru. }\end{array}$ & 4,60 & 0,88 \\
\hline 29 & * Často pro mě bylo těžké zjistit, co se ode mě v předmětu očekává. & 4,05 & 1,05 \\
\hline & Přiměřené hodnocení (PH) & a. p. & s. o. \\
\hline & & & \\
\hline
\end{tabular}




\begin{tabular}{llcc}
\hline 13 & $\begin{array}{l}\text { * Vyučující se zajímal/a více o testování toho, co jsem si } \\
\text { zapamatoval/a, než toho, co jsem pochopil/a. }\end{array}$ & 2,33 & 1,07 \\
\hline 20 & * Vyučující se mě ptal/a pouze na fakta. & 2,72 & 0,97 \\
\hline 26 & $\begin{array}{l}* \text { Abyste si v tomto předmětu vedli dobře, potřebovali jste jen dobrou } \\
\text { pamět'. }\end{array}$ & 2,59 & 1,19 \\
\hline & Přiměřená zátěž (PZ) & 1,84 & 0,89 \\
\hline 2 & *V předmětu jsem byl/a jako student/a pod velkým tlakem. & 2,20 & 0,93 \\
\hline 4 & * Pracovní zátěž byla př́liš velká. & 1,89 & 1,03 \\
\hline 15 & $\begin{array}{l}\text { Většinou jsem měl dostatek času na pochopení věcí, které se musím } \\
\text { naučit. }\end{array}$ & 1,89 & 0,93 \\
\hline 24 & $\begin{array}{l}* \text { Objem učiva, který bylo pro tento předmět třeba zvládnout, byl } \\
\text { takový, že látku nešlo zcela pochopit. }\end{array}$ & a. p. & s. o. \\
\hline & Obecné dovednosti (OD) & 2,84 & 1,20 \\
\hline 5 & Předmět mi pomohl rozvinout schopnost pracovat jako člen týmu. & 3,32 & 0,99 \\
\hline 9 & Předmět zlepšil mou dovednost analyticky pracovat s informacemi. & 3,32 \\
\hline 10 & Díky předmětu se cítím jistější při řešení neznámých problémů. & 2,97 & 1,04 \\
\hline 18 & Předmět rozvinul mou dovednost řešit problémy. & 3,09 & 1,09 \\
\hline 22 & Předmět zlepšil mé dovednosti v písemné komunikaci. & 3,10 & 1,14 \\
\hline 23 & Předmět mi pomohl rozvinout schopnost plánovat si práci. & 2,99 & 1,17 \\
\hline & Celkově jsem byl/a s výukou spokojen/a. & 3,99 & 1,11 \\
\hline
\end{tabular}

* = obrácená hodnota škály na položce

a. p. = aritmetický průměr; s. o. = směrodatná odchylka

\subsection{Konfirmační faktorová analýza}

Pro ověřování konstruktové validity modelu jsme vyšli především ze zjištění autorů, kteří prezentovali výsledky testování originální verze CEQ23 u absolventů (Wilson, Lizzio, \& Ramsden, 1997) nebo jí analogického SCEQ u studentů (Ginns, Prosser, \& Barrie, 2007). Celý proces proběhl ve třech po sobě jdoucích krocích. Vzhledem k teoreticky předpokládaným i empiricky potvrzeným vzájemným korelacím všech dotazníkových škál byl v prvním kroku testován pětifaktorový model se vzájemnou korelací všech faktorů (M1). Protože se vzájemné korelace některých škál ukázaly jako značně vysoké, testovanou alternativou k pětifaktorovému modelu byl model jednofaktorový (M2). Poslední krok zahrnoval testování hierarchických modelů s různým počtem faktorů druhého řádu (M3). Jeho výsledky pomohly objasnit otázku vhodnosti utvoření celkového skóre dotazníku. 
V rámci výsledků konfirmační faktorové analýzy byly sledovány hodnoty standardizovaných regresních koeficientů indikátorů na př́slušných faktorech, vzájemné korelace faktorů a v neposlední řadě celkové ukazatele shody dat s modelem. Z absolutních kritérií to bylo AGFI (adjusted goodness-of-fit-index), kde hodnoty nad 0,9 indikují vhodný model. Vzhledem k tomu, že toto kritérium je závislé na velikosti souboru, bylo využito ještě dalších kritérií. Ze srovnávacích kritérií jsme se zaměřili na CFI (Comparative Fit Index) a TLI (Tucker-Lewis Index) porovnávající kvalitu věrohodnosti modelu s modelem nezávislosti. Doporučené hodnoty pro oba indexy jsou nad 0,9. Dalším sledovaným kritériem bylo RMSEA (Root Mean Square Error of Approximation) vypovídající o chybovosti modelu, jehož doporučené hodnoty pro dobrý model by neměly překročit 0,08 . K vzájemnému porovnání testovaných alternativních modelů byla použita dvě informační kritéria, konkrétně AIC (Akaike Information Criterion) a BIC (Bayesian Information Criterion). Pro hodnocení validity v rámci jednoho modelu jsme využili porovnání hodnot AIC a BIC našeho modelu s modelem saturovaným (model $\mathrm{s}$ maximálně možným počtem parametrů). $V$ př́padě dobré shody modelu s daty by hodnoty AIC i BIC u našeho modelu měly být nižší nebo stejné jako hodnoty pro saturovaný model. Pro porovnání validity u alternativních modelů jsme se řídili pravidlem o více než deset jednotek nižších hodnotách indikujících lepší model (Raftery, 1995, cit. dle Soukupa, v tisku).

Vzhledem k tomu, že data získaná z odpovědí na pětibodové škále mají charakter kratších ordinálních škál a metoda odhadu ML ${ }^{15}$ v SPSS AMOS ordinalitu škál na rozdíl od metod jako jsou polychorické korelace (např postup WLSMW v softwaru R) plně nezohledňuje, bylo třeba vzít v úvahu, že výsledky ukazatelů shody budou horší nežli při použití zohledňujících metod, a upřednostnit úspornost $\mathrm{v}$ případných zásazích. $\mathrm{Z}$ těchto důvodů byly realizovány pouze modifikace, které výrazně přispívají ke zlepšení shody modelu s daty.

\subsubsection{CEQ23: pětifaktorový model}

Ověřování shody celkového pětifaktorového modelu s daty předcházelo ověření validity modelů dílčích škál. Tyto výsledky na tomto místě neprezentujeme, pouze konstatujeme, že modely všech dílčích škál měly uspokojivé indexy

15 ML (Maximum Likelihood), metoda maximální věrohodnosti, jedna z nejčastěji používaných technik odhadu neznámých parametrů ve strukturním modelování, která je založena na pozorovaných datech a je vhodná především pro spojité proměnné (Soukup, v tisku). 
shody s daty a obešly se bez modifikací. Testování pětifaktorového modelu se vzájemně korelovanými faktory (M1) proběhlo hned poté a s výsledky zobrazenými pod označením M1.1 a M1.2 v tabulce 3.

Konfirmační analýza provedená metodou ML v SPSS AMOS u pětifaktorového modelu se vzájemně korelovanými všemi faktory ukázala poměrně uspokojivé výsledky. Hodnoty AGFI, CFI a TLI dosáhly nebo téměř dosáhly doporučované výše, chybovost modelu vyjádřená kritériem RMSEA je v doporučovaném limitu. Informační kritéria AIC a BIC v porovnání se saturovaným modelem naznačují, že model by mohl být ještě vylepšen (hodnoty u testovaného modelu by měly být nižší). Při pohledu do navrhovaných modifikačních ukazatelů se jako jednoznačný návrh na úpravu jevilo povolení korelace chyb měření u položek 2 a 4 . Po obsahovém vyhodnocení obou položek (2: „V předmětu jsem byl/a jako student/a pod velkým tlakem“; 4: „Pracovní zátěž byla př́liš velká") bylo možné souhlasit, že položky sdílí společný význam více nežli s položkami ostatními, a modifikaci povolit. Testování modelu s touto jedinou modifikací (M1.2) přineslo zlepšení, které je nejvíce patrné u informačního kritéria BIC, u něhož bylo dosaženo nižší hodnoty v porovnání se saturovaným modelem. S tímto výsledkem bylo již možné se $\mathrm{s}$ ohledem na metodu výpočtu zcela spokojit. Hodnoty standardizovaných regresních koeficientů jednotlivých položek na př́slušných faktorech a vzájemné korelace škál u modelu M1.2 prezentuje tabulka 2. Je z ní patrné, že standardizované regresní zátěže položek na většině faktorů jsou přijatelně vysoké. Nejnižší hodnota se objevuje u položky 4 . Výsledný model je vizualizován obrázkem 1.

Tabulka 2

Standardizované regresní koeficienty položek dotazníku a korelace faktorů výsledného modelu M1.2

\begin{tabular}{llllll}
\hline & \multicolumn{5}{c}{ Faktorové zátěže } \\
\cline { 2 - 6 } & DV & JSC & PH & PZ & OD \\
\hline Dobrá výuka (DV) & & & & & \\
\hline $\begin{array}{l}\text { 8. Vyučující mě v předmětu motivoval/a k tomu, } \\
\text { abych odvedl/a co nejlepší práci. }\end{array}$ & 0,79 & 0 & 0 & 0 & 0 \\
\hline $\begin{array}{l}\text { 21. Vyučující se snažil/a, aby jeho/její předmět byl } \\
\text { zajímavě podaný. }\end{array}$ & 0,78 & 0 & 0 & 0 & 0 \\
\hline $\begin{array}{l}\text { 16. Vyučující se snažil/a pochopit moje obtíže } \\
\text { spojené s prací v předmětu. }\end{array}$ & 0,71 & 0 & 0 & 0 & 0 \\
\hline $\begin{array}{l}\text { 3. Vyučující mi poskytoval/a užitečnou zpětnou } \\
\text { vazbu o tom, jak jsem si v předmětu vedl/a. }\end{array}$ & 0,69 & 0 & 0 & 0 & 0 \\
\hline \begin{tabular}{l} 
19. Vyučující uměl/a látku dobře vysvětlit. \\
\hline
\end{tabular} & 0,75 & 0 & 0 & 0 & 0 \\
\hline
\end{tabular}




\begin{tabular}{|c|c|c|c|c|c|}
\hline & \multicolumn{5}{|c|}{ Faktorové zátěže } \\
\hline & DV & JSC & $\mathrm{PH}$ & $\mathrm{PZ}$ & OD \\
\hline $\begin{array}{l}\text { 27. Vyučující věnoval/a dostatek času komentování } \\
\text { mé práce. }\end{array}$ & 0,63 & 0 & 0 & 0 & 0 \\
\hline \multicolumn{6}{|l|}{ Jasné cíle a standardy (JCS) } \\
\hline $\begin{array}{l}\text { 6. Měl/a jsem jasnou představu o tom, kam směřuji } \\
\text { a co se ode mě v předmětu očekává. }\end{array}$ & 0 & 0,82 & 0 & 0 & 0 \\
\hline $\begin{array}{l}\text { 12. Standard toho, co se od studentů v předmětu } \\
\text { očekávalo, byl dobře známý. }\end{array}$ & 0 & 0,78 & 0 & 0 & 0 \\
\hline $\begin{array}{l}\text { * 29. Často pro mě bylo těžké zjistit, co se ode mě } \\
\text { v předmětu očekává. }\end{array}$ & 0 & 0,75 & 0 & 0 & 0 \\
\hline $\begin{array}{l}\text { 25. Požadavky na studenty byly vyučujícím } \\
\text { stanoveny od začátku semestru. }\end{array}$ & 0 & 0,52 & 0 & 0 & 0 \\
\hline \multicolumn{6}{|l|}{ Přiměřené hodnocení (PH) } \\
\hline * 20. Vyučující se mě ptal/a pouze na fakta. & 0 & 0 & 0,62 & 0 & 0 \\
\hline $\begin{array}{l}\text { * } 13 \text {. Vyučující se zajímal/a více o testování toho, } \\
\text { co jsem si zapamatoval/a, než toho, co jsem } \\
\text { pochopil/a. }\end{array}$ & 0 & 0 & 0,59 & 0 & 0 \\
\hline $\begin{array}{l}* 26 . \text { Abyste si v tomto předmětu vedli dobře, } \\
\text { potřebovali jste jen dobrou pamět'. }\end{array}$ & 0 & 0 & 0,56 & 0 & 0 \\
\hline \multicolumn{6}{|l|}{ Přiměřená zátěž (PZ) } \\
\hline $\begin{array}{l}\text { 15. Většinou jsem měl/a dostatek času na } \\
\text { pochopení věcí, které se musím naučit. }\end{array}$ & 0 & 0 & 0 & 0,73 & 0 \\
\hline $\begin{array}{l}\text { * } 24 \text {. Objem učiva, který bylo pro tento předmět } \\
\text { třeba zvládnout, byl takový, že látku nešlo zcela } \\
\text { pochopit. }\end{array}$ & 0 & 0 & 0 & 0,67 & 0 \\
\hline $\begin{array}{l}\text { * 2. V předmětu jsem byl/a jako student/a pod } \\
\text { velkým tlakem. }\end{array}$ & 0 & 0 & 0 & 0,53 & 0 \\
\hline * 4. Pracovní zátěž byla př́liš velká. & 0 & 0 & 0 & 0,37 & 0 \\
\hline \multicolumn{6}{|l|}{ Obecné dovednosti (OD) } \\
\hline $\begin{array}{l}\text { 18. Předmět rozvinul mou dovednost řešit } \\
\text { problémy. }\end{array}$ & 0 & 0 & 0 & 0 & 0,79 \\
\hline $\begin{array}{l}\text { 10. Díky předmětu se cítím jistější při řešení } \\
\text { neznámých problémů. }\end{array}$ & 0 & 0 & 0 & 0 & 0,76 \\
\hline $\begin{array}{l}\text { 22. Předmět zlepšil mé dovednosti v písemné } \\
\text { komunikaci. }\end{array}$ & 0 & 0 & 0 & 0 & 0,72 \\
\hline $\begin{array}{l}\text { 23. Předmět mi pomohl rozvinout schopnost } \\
\text { plánovat si práci. }\end{array}$ & 0 & 0 & 0 & 0 & 0,69 \\
\hline $\begin{array}{l}\text { 9. Předmět zlepšil mou dovednost kriticky pracovat } \\
\text { s informacemi. }\end{array}$ & 0 & 0 & 0 & 0 & 0,65 \\
\hline $\begin{array}{l}\text { 5. Předmět mi pomohl rozvinout schopnost } \\
\text { pracovat jako člen týmu. }\end{array}$ & 0 & 0 & 0 & 0 & 0,61 \\
\hline Vzájemné korelace faktorů (Pearsonův koeficient) & DV & JSC & $\mathrm{PH}$ & $\mathrm{PZ}$ & OD \\
\hline
\end{tabular}




\begin{tabular}{lccccc}
\hline & \multicolumn{5}{c}{ Faktorové zátěže } \\
\cline { 2 - 6 } & DV & JSC & PH & PZ & OD \\
\hline Dobrá výuka (DV) & 1 & & & & \\
\hline Jasné cíle a standardy (JSC) & 0,82 & 1 & & & \\
\hline Přiměřené hodnocení (PH) & 0,41 & 0,25 & 1 & & \\
\hline Přiměřená zátěž (PH) & 0,72 & 0,74 & 0,47 & 1 & \\
\hline Obecné dovednosti (OD) & 0,76 & 0,52 & 0,29 & 0,43 & 1 \\
\hline
\end{tabular}

* = obrácená hodnota škály na položce

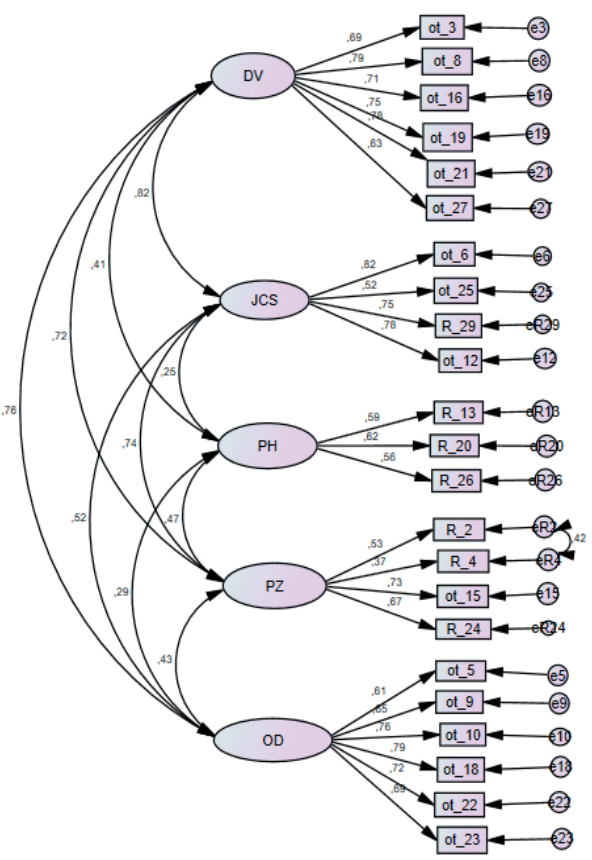

Obrázek 1. Výsledný model faktorové struktury české verze dotazníku CEQ (M1.2). 


\subsubsection{CEQ23: jednofaktorový model}

Vzhledem ke zjištěním o vysokých vzájemných korelacích faktorů dosahujících nebo téměř dosahujících hodnoty 0,8 , se nabízela otázka, zda namísto rozlišování odpovědí studentů na položky dotazníku do očekávaných pěti dimenzí není vhodnějším modelem jediný faktor sycený všemi položkami. Ke konfirmační faktorové analýze byl tedy podstoupen model s jedním společným faktorem, jehož výsledky (viz M2) a porovnání s modelem pětifaktorovým (M1.1 a M1.2) shrnuje tabulka 3. Jak vypovídají hodnoty ukazatelů shody, model s jedním faktorem je podstatně horší nežli model pětifaktorový, což vedlo k jednoznačnému zamítnutí hypotézy o existenci jediného faktoru pro konstrukt vnímaného kontextu výuky měřený dotazníkem CEQ23 v českém prostředí.

Tabulka 3

Hodnoty srovnávacích kritérií u testovaných alternativních modelů

\begin{tabular}{lrrr}
\hline CFA & M1.1 & M1.2 & M2 \\
\hline Popis modelu & $\begin{array}{l}\text { pětifaktorový model } \\
\text { bez modifikací }\end{array}$ & $\begin{array}{l}\text { pětifaktorový model } \\
\text { s jednou modifikací } \\
\text { (kovariance chyb } \\
\text { položek 2 a 4) }\end{array}$ & $\begin{array}{l}\text { jednofaktorový model } \\
\text { bez modifikací }\end{array}$ \\
\hline Cmin & 780,323 & 675,453 & 2404,306 \\
\hline Df & 220 & 219 & 230 \\
\hline P & $<0,001$ & $<0,001$ & $<0,001$ \\
\hline Cmin/df & 3,547 & 3,084 & 10,408 \\
\hline AGFI & 0,875 & 0,890 & 0,654 \\
\hline RMSEA & 0,063 & 0,057 & 0,121 \\
\hline CFI & 0,911 & 0,927 & 0,654 \\
\hline TLI & 0,898 & 0,916 & 0,622 \\
\hline AIC & 892,323 & 789,453 & 2494,306 \\
\hline AIC sat.* & 552,0 & 552,0 & 2652,0 \\
\hline BIC & 1142,775 & 1044,376 & 1786,368 \\
\hline BIC sat. & 1786,368 & 1786,368 & \\
\hline
\end{tabular}

\footnotetext{
* hodnoty vypočítané pro tzv. saturované modely
} 


\subsubsection{CEQ23: hierarchické modely}

Poslední otázkou testovanou prostřednictvím konfirmační faktorové analýzy byla vhodnost vytvoření celkového skóre dotazníku. Odpovědi poskytlo testování hierarchických modelů $s$ různým počtem faktorů druhého řádu (M3). Tato otázka byla v minulosti několikrát testována zahraničními autory. Trigwell a Prosser (1991a) potvrdili jediný faktor druhého řádu a podobně také Richardson (1994). Na podnět Ramsdena (1991), který předpokládal, že CEQ může zahrnovat dva faktory druhého řádu, jeden sycený Dobrou výukou a Přiměřeným hodnocení a druhý Přiměřenou zátěží, kolektiv Wilsonová, Lizzio a Ramsden (1997) testoval tři alternativní hierarchické modely: jednofaktorový model druhého řádu, dvoufaktorový model druhého řádu, kde jeden faktor představuje Přiměřená zátěž a druhý všechny ostatní škály, a třífaktorový model druhého řádu rozlišující mezi Přiměřenou zátěží, Obecnými dovednostmi a všemi ostatními škálami. Výsledky testování na dvou velkých souborech dat z let 1993 a 1992 ukázaly nejlepší shodu s daty u dvoufaktorového modelu druhého řádu.

Námi realizované testování replikovalo ověřování všech třech modelů a jeho výsledky jsou k nalezení v tabulce 4 (M3.1, M3.2 a M3.3). Modely faktorů druhého řádu nebyly vzájemně korelovány. Jak vyplývá z výsledků, model M3.1 má nejpř́íznivější ukazatele shody s daty a je zároveň nejjednodušší, proto můžeme konstatovat, že na základě našich dat je možné výsledky získané na jednotlivých škálách agregovat do jednoho celkového skóre vystihujícího vnímanou kvalitu výuky.

Tabulka 4

Hodnoty srovnávacích kritérií u alternativních hierarchických modelů

\begin{tabular}{llllr}
\hline CFA & M3.1 & M3.2 & \multicolumn{2}{l}{ M3.3 } \\
\hline Popis modelu & $\begin{array}{l}\text { jednofaktorový } \\
\text { hierarchický model }\end{array}$ & $\begin{array}{l}\text { dvoufaktorový } \\
\text { hierarchický model } \\
\text { (PZ a ostatní škály) }\end{array}$ & $\begin{array}{l}\text { tř́faktorový } \\
\text { hierarchický model } \\
\text { (PZ, OD a ostatní škály) }\end{array}$ \\
\hline Cmin & 860,735 & 1052,171 & 1411,18514 \\
\hline Df & 225 & 226 & 227 \\
\hline P & $<0,001$ & $<0,001$ & 6,217 \\
\hline Cmin/df & 3,825 & 4,656 & 0,812 \\
\hline AGFI & 0,865 & 0,853 & 0,090 \\
\hline RMSEA & 0,066 & 0,075 & \\
\hline
\end{tabular}




\begin{tabular}{llrlr}
\hline CFA & M3.1 & M3.2 & \multicolumn{2}{l}{ M3.3 } \\
\hline Popis modelu & $\begin{array}{l}\text { jednofaktorový } \\
\text { hierarchický model }\end{array}$ & $\begin{array}{l}\text { dvoufaktorový } \\
\text { hierarchický model } \\
\text { (PZ a ostatní škály) }\end{array}$ & $\begin{array}{l}\text { tř́faktorový } \\
\text { hierarchický model } \\
\text { (PZ, OD a ostatní škály) }\end{array}$ \\
\hline CFI & 0,899 & 0,869 & 0,812 \\
\hline TLI & 0,886 & 0,853 & 0,790 \\
\hline AIC & 962,735 & 1156,029 & 1509,185 \\
\hline AIC sat.* & 552,0 & 552,0 & 552,0 \\
\hline BIC & 1190,825 & 1375,788 & 1728,330 \\
\hline BIC sat.* & 1789,368 & 1789,368 & 1786,368 \\
\hline
\end{tabular}

Jednoduchý výpočet pro rychlé využití v praxi by představoval pouze součet průměrů skóre získaného pro jednotlivé škály. Tato skóre by se získala výpočtem průměru hodnot příslušných položek. Přesnější způsob využitelný např́klad pro výzkumné účely by vyšel z váženého průměru. Jako váha hodnot na jednotlivých faktorech by se použila faktorová skóre z modelu s jedním faktorem druhého řádu. Alternativně by bylo možné využít také hodnot $\mathrm{z}$ modelu s jedním faktorem prvního řádu, kdy by váhami byly vážené průměry jednotlivých položek.

\subsection{Vnitřní konzistence škál}

V dalším kroku byla ověřována vnitřní konzistence škál dotazníku CEQ. Výsledky shrnuje tabulka 5, která zároveň obsahuje výsledky získané autory dvou šetření s použitím originální verze CEQ na velkých datových souborech.

Z našich výsledků je patrné, že vnitřní konzistence jednotlivých škál je relativně blízká hodnotám získaným na velkých souborech originální verzí dotazníku. Oproti originální verzi má česká poněkud nižší konzistenci u škály Přiměřené hodnocení $(0,61)$, a naopak vyšší u škály Obecné dovednosti $(0,85)$. V př́ípadě škály Přiměřené hodnocení byly prezentovány problémy s vnitřní konzistencí také autory několika dalších jazykových verzí (Richardson, 1994; Espeland \& Indrehus, 2003; Law \& Meyer, 2011; Thien \& Ong, 2014), z nichž někteř́ museli od zařazení této škály ustoupit. Tato skutečnost může naznačovat, že reprezentace přiměřeného hodnocení může podléhat kulturním specifikům. $V$ našem prrípadě však hodnoty nebyly tak nízké, aby je nebylo možné v dotazníku ponechat. 
Tabulka 5

Vnitřní konzistence škál originální a české verze CEQ včetně intervalů spolehlivosti (CI)

\begin{tabular}{lcccc}
\hline Škála & N & \multicolumn{3}{c}{ Cronbach alfa } \\
\cline { 3 - 5 } & & Wilson et al., $1997^{*}$ & Ginns et al., 2007 & Tato studie \\
\hline DV & 6 & 0,88 & $0,83(95 \%$ CI 0,826-0,837) & $0,87(95 \%$ CI 0,852-0,883) \\
\hline JCS & 4 & 0,76 & $0,80(95 \%$ CI 0,781-0,805) & $0,81(95 \%$ CI 0,789-0,836) \\
\hline PH & 3 & 0,70 & $0,72(95 \%$ CI 0,703-0,725) & $0,61(95 \%$ CI 0,557-0,661) \\
\hline PZ & 4 & 0,69 & $0,76(95 \%$ CI 0,753-0,770) & $0,72(95 \%$ CI 0,685-0,755) \\
\hline OD & 6 & 0,77 & $0,77(95 \%$ CI 0,755-0,771) & $0,85(95 \%$ CI 0,831-0,867) \\
\hline
\end{tabular}

* autoři neprezentují hodnoty intervalů spolehlivosti

\subsection{Korelace škál CEQ s celkovou spokojeností s výukou}

Jednou z možností dokladování validity dotazníku je zjišt'ovat vztahy jeho škál k vnějšímu kritériu. Ramsden ve své původní studii (1991) využil trojího typu vnějšího kritéria $\mathrm{k} C E Q$ - kvality procesů učení studentů měřené dotazníkem ASI (Entwistle, Hanley, \& Hounsell, 1979), spokojenosti studentů s výukou a míry shody mezi hodnocením předmětů studenty a vyučujícími. $V$ př́padě námi realizovaných analýz bylo jako vnějšího kritéria využito položky vyjadřující celkovou spokojenost studentů s výukou, která byla součástí administrovaného dotazníku („Celkově jsem byl/a s výukou spokojen/a").

Spokojenost s kvalitou kurzu je podle autorů dotazníku emoční a behaviorální odpovědí na kognitivní hodnocení kurzu, které je operacionalizováno prostřednictvím pěti ostatních indexů. Jako taková může být kompletním obrazem spokojenosti studenta, která je založena na řadě podmínek, z nichž pouze některé zjištuje CEQ (Ramsden, 1991). Korelace položky celkové spokojenosti s výukou se všemi ostatními škálami CEQ by proto měly podle Ramsdena být signifikantní, ale ne natolik vysoké, aby je bylo možné se spokojeností zcela ztotožnit. Výsledky získané námi provedenou analýzou jsou $\mathrm{v}$ tabulce 6 doplněny těmi, které v roce 1991 prostřednictvím verze CEQ30 získal ve zkušebním národním testování Ramsden. Hodnoty Pearsonova koeficientu na českých datech jsou shodně s Ramsdenovými všechny významné, nejnižší korelace dosahuje škála Přiměřená zátěž, naopak nejvyšší Dobrá výuka. 
Tabulka 6

Pearsonův korelační koeficient mezi dimenzemi a celkovou spokojeností s výukou

\begin{tabular}{lcc}
\hline Škála & \multicolumn{2}{c}{ Celková spokojenost s výukou } \\
\cline { 2 - 3 } & $\begin{array}{c}\text { CEQ30 } \\
\text { Ramsden (1991) }\end{array}$ & $\begin{array}{c}\text { CEQ23 } \\
\text { Tato studie }\end{array}$ \\
\hline Dobrá výuka (DV) & 0,60 & 0,75 \\
\hline Jasné cíle a standardy (JCS) & 0,47 & 0,65 \\
\hline Přiměrené hodnocení (PH) & 0,40 & 0,46 \\
\hline Přiměřená zátěž (PZ) & 0,21 & 0,27 \\
\hline Důraz na nezávislost (DN) & 0,40 & - \\
\hline Obecné dovednosti & - & 0,57 \\
\hline
\end{tabular}

\section{Diskuse}

Námi testovaná verze dotazníku CEQ má 24 položek, s předpokládanou př́islušností 23 z nich k pěti dimenzím. Poslední položka zjišt'uje celkovou spokojenost s výukou a po vzoru zahraniční verze dotazníku byla připojena za účelem validace dotazníku. $V$ rámci naší studie byly sledovány dva cíle: (1) ověřit faktorovou strukturu dotazníku v českém prostředí; (2) v návaznosti na výsledky analýz vyslovit závěry o možnostech a mezích využitelnosti tohoto nástroje pro hodnocení kvality výuky v aktuálních podmínkách českých vysokých škol. V následujících oddílech se k těmto otázkám vyjádříme, pojmenujeme limity studie a naznačíme další možnosti ve směru testování a úprav dotazníku.

\subsection{Dotazníková struktura a podněty k úpravám}

Realizované analýzy potvrdily pětifaktorovou strukturu CEQ23 na vzorku českých vysokoškoláků. Na jejich základě je možné konstatovat, že čeští studenti nereprezentují kvalitu výukového kontextu výrazně odlišně v porovnání se studenty v Austrálii a mnoha dalších zemích, kde tato struktura byla rovněž potvrzena (např. Severní Irsko, Dánsko, Norsko, Řecko, Pákistán, Thajsko, Holandsko a Etiopie), čímž se společně s nimi odlišují např́klad od studentů z Indie, Malajsie, Japonska a Hongkongu, na jejichž datech dotazníková struktura jednoznačně potvrzena nebyla (podrobněji viz Juklová et al., 2019). Interpretace těchto odlišností je vzhledem k odlišnostem v použitých 
analytických metodách poněkud problematická. $\mathrm{V}$ rámci dříve publikovaného přehledu je možné vysledovat trend, kdy adaptace realizované před rokem 2000 zpravidla využívají explorační faktorovou analýzu a často dospívají k odchylkám od původního modelu. Oproti tomu jazykové verze realizované později, k jejichž ověřování autoři využili již jen konfirmační analytický postup, obvykle dospívají k potvrzení všech originálních dotazníkových dimenzí, a to i v takových kulturách, jako je například Čína, Thajsko, Etiopie nebo Chile. K získání spolehlivější odpovědi na charakter rozdílů mezi jednotlivými kulturními prostředími by proto bylo nutné nejprve testovat jejich srovnatelnost (ekvivalenci).

I přes velmi př́znivé výsledky přinesly naše analýzy několik podnětů k dalším možným úpravám české verze dotazníku a $\mathrm{k}$ budoucím analýzám. Relativně nízké hodnoty regresních koeficientů na faktorech některých položek (viz položka 25 u faktoru JCS a položky 2 a 4 u faktoru PZ) naznačují jejich ne právě ideální výstižnost a vytváří prostor pro jejich budoucí stylistickou reformulaci.

Obsahová analýza dvou otevřených otázek ${ }^{16}$, které byly připojeny $\mathrm{k}$ námi testovanému dotazníku, naznačila některé doplňující informace o pojetí výuky studenty. Nad rámec pojmenovaných dimenzí např́íklad vynikla zmínka 178 studentů o osobnosti vyučující/ho jako aspektu, který významně přispěl ke kvalitě výuky. Dále 24 studentů zmínilo důležitost skupiny spolužáků a spolupráce s nimi. Naopak největší kritika byla pronášena na vrub pracovní zátěže (uvedlo 67 respondentů) chápané jako nedostatek času na práci, př́íliš rychlý výklad, př́liš mnoho dílčích úkolů, které se nejeví jako využitelné v budoucí praxi. Jako důležitý podnět pro potenciální zlepšení výuky byla dále vyzdvižena komunikace vyučující/ho (58 respondentů), chápaná jako způsob komunikace, tempo, forma, hlasitost, jednotvárnost, srozumitelnost, zábavnost, zajímavost, záživnost, zdlouhavost či zmatenost výkladu vyučující/ho, a zázemí k předmětu (20 respondentů), které studenti chápali jako zapůjčování pomůcek katedrou, přístupnost materiálů pro výuku, vybavení třídy, zajištění prostor pro výuku (učebnu odpovídající stylu výuky). Za nejvíce znepokojivé studenti v rámci volných výpovědí zmiňovali nejasnost cílů a standardů (53 respondentů) ve smyslu přesnosti požadavků na studenty (vyjasnění toho, co se od nás v predmětu očekává), požadavků ke zkoušce,

${ }_{16}$ „Které aspekty předmětu nejvíce přispívaly k jeho kvalitě?“; „Které aspekty předmětu by potřebovaly nejvíce zlepšit?" 
požadavků na nastudovanou literaturu; na druhé straně tím rozuměli lepší organizaci výuky, strukturovanost a uspořádanost výkladu (vědět více, co si máme zapsat). Č́ast studentů (24) také volala po větším rozvíjení dovedností ve směru uvádění více praktických příkladů, které by propojovaly teorii s praxí, více se mělo pracovat ve skupinách a týmech či rozvíjet konkrétní dovednosti (např. zaměřit se více na výklad počítačových dovedností, aby práce hodnotila komise a ne jen 1 pedagog). Přestože tyto výpovědi mohou být specifické pro daný typ vysoké školy, mohou být při úvahách o porozumění studentů položkám vzaty v potaz.

\subsection{Celková spokojenost s výukou jako vněǰš́ kritérium}

Pro ověřování kriteriální validity dotazníku jsme jako vnějšího kritéria využili položky celkové spokojenosti s výukou. Vztah mezi položkou celkové spokojenosti s výukou a ostatními škálami dotazníku se pokusili ve své studii objasnit Graceová s kolegy (2012). Použili metodu strukturního modelování a vztah mezi jednotlivými dimenzemi dotazníku včetně celkové spokojenosti studenta ověřvali v sekvenčním modelu. Ten sledoval vzájemné vztahy jednotlivých dimenzí na úrovni průvodních proměnných, tzv. antecedentů (Dobrá výuka, Jasné cíle a standardy, Přiměřená zátěž a Přiměřené hodnocení), a výsledných proměnných tvořených Obecnými dovednostmi a Celkovou spokojeností s výukou. Výsledky potvrdily, že klíčovými antecedenty pro následný rozvoj obecných dovedností a pro celkovou spokojenost jsou Dobrá výuka a Jasné cíle a standardy, nikoli však Přiměřená zátěž a Přiměřené hodnocení. Obecné dovednosti byly zároveň mediátorem vztahu mezi Dobrou výukou, Jasnými cíli a standardy a Celkovou spokojeností. Celková spokojenost s výukou byla v sekvenčním modelu podle předpokladu autorů $\mathrm{v}$ pozici výsledné proměnné. Na základě těchto zjištění autoři potvrdili, že položka celkové spokojenosti, v některých dotazníkových verzích též index tvořený několika položkami, není totožná s výsledným vnímáním kvality výuky měřeným dotazníkem, ale má naopak potenciál přinést emoční výpověd' o širší zkušenosti studenta v porovnání s tou, která je hodnocena ostatními položkami dotazníku.

Přestože položka celkové spokojenosti s výukou má pro zjištování kvality vnímané výuky empiricky odůvodněný prínos, budoucí ověřování validity dotazníku může být rozšířeno o další vnější kritéria, z nichž jedním je koncept studentova př́stupu k učení. Dotazník CEQ vznikl jako indikátor kvality výkonu v dimenzích, které byly empiricky ověřeny jako vedoucí ke kvalitnímu 
učení konceptualizovanému jako hloubkový přístup k učení (Marton \& Saljö, 1976; Biggs, 1993; Marton \& Pang, 2006). V budoucnu proto považujeme za vhodné ověřit vztah dotazníkových škál s hloubkovými a povrchovými př́istupy k učení. Koncept hloubkového a povrchového př́ístupu k učení není kulturně zcela nezávislý (Meyer \& Parsons, 1989; Maramble et al., 2012; Vermunt et al., 2014) a jeho hodnoty v našich podmínkách nejsou ani př́iliš rozšiřené, a proto je možné očekávat, že některé odlišnosti v pedagogické kultuře českého prostředí od kultur anglofonních mohou mít vliv na odlišný způsob reprezentování kvality výuky ve vztahu k př́ístupům učení.

\subsection{Charakter výběrového souboru jako omezení studie}

Za nejvýraznější limit této studie považujeme skutečnost, že respondenti našeho výzkumu byli pouze studenti učitelských oborů a jedné instituce a dominantně byli zastoupeni respondenti ženského pohlaví (82,1 \%). Genderové rozdíly v hodnocení výuky byly v minulosti jednoznačně dokumentovány (Al-Harthi, 2005; Grebennikov \& Skaines, 2009; Richardson \& King, 1991). Ženy se projevují jako více vnímavé k chování a vzdělávacímu diskurzu (Smith, 2004), zároveň jako konformnější a svědomitější a více ocenuující spolupracující prostředí. Na druhou stranu jsou studentky oproti svým mužským protějškům úzkostnější, méně sebevědomé a disponují větším strachem ze selhání (Chapman, 1996). V hodnocení výuky se např́íklad ukázalo, že studentky hodnotí své pedagogy příznivěji nežli studenti, a to bez ohledu na jejich gender. Studentky se cítí s výukou spokojené pouze tehdy, rozvinula-li výuka jejich dovednosti. Muži udávají spokojenost v souvislosti s kvalitou výuky bez ohledu na to, zda si ověřili rozvoj dovedností, což je přisuzováno jejich vyššímu sebehodnocení (Grace et al., 2012). V obdobném duchu mohla výsledky zkreslit skutečnost, že respondenty byli studenti pouze jedné instituce. $\mathrm{V}$ této souvislosti by bylo v budoucnu vhodné využít reprezentativnější data z různých vysokoškolských institucí a spolu s celkovou konstruktovou validitou rovněž ověřit ekvivalenci modelu mezi různě zaměřenými institucemi.

\subsection{Možnosti a limity využití dotazníku pro evaluaci vysokoškolské výuky $v$ českém prostredí}

Námi provedená úprava dotazníku se v porovnání s originální verzí odlišuje úrovní, na níž je studijní zkušenost měřena. Oproti původnímu dotazníku měřícímu globální studijní zkušenost byla česká verze po vzoru některých 
dalších autorů (Steele, West, \& Simeon, 2003; Ginns \& Barrie, 2004; Bell, Galilea, \& Tolouei, 2010; Sorensen, 2013; Liu et al., 2017) adaptována pro zjišt'ování studijní zkušenosti v jednom předmětu. Výhodou měření na této úrovni je ve vztahu k aktuálnímu požadavku na vysokoškolské instituce předkládat realizovanou autoevaluaci a zajištovat kvalitu především okamžitá a cílená zpětná vazba pro konkrétní osobu a v případě agregování dat i pro oddělení nebo vyšší celky, na jejímž základě je možné rychle reagovat opatřeními vedoucími ke zkvalitňování výuky.

Námi adaptovaná verze CEQ23 je vysoce použitelná pro hodnocení výuky $\mathrm{v}$ náhodně nebo záměrně zvolených předmětech $\mathrm{v}$ rámci potřeby ověření efektu změn a inovací. Pro průběžně prováděnou plošnou autoevaluaci instituce, kdy je třeba získat data ze všech předmětů, je však tato verze stále poněkud dlouhá. Pokud by se studenti měli prostřednictvím 24 položek vyjadřovat ke všem předmětům, které $\mathrm{v}$ uplynulém semestru absolvovali, pak se může délka dotazníku stát faktorem, který bude snižovat jejich ochotu odpovídat. Pro tyto př́ípady je možné po vzoru australských kolegů používat jeho zkrácenou verzi utvořenou z položek nejvíce sytících každou škálu. Zároveň je možné škálu Obecné dovednosti nahradit pro každý obor / studijní program / předmět specifickými očekávanými výstupy, doplnit nízký počet dotazníkových položek o možnost otevřeného vyjádření se k nim nebo možnost zdůvodnění svého číselného hodnocení (tato verze je př́lohou tohoto textu). Podrobné náměty a zkušenosti s integrací zpětné vazby do systému zajištování kvality vysokoškolské instituce je možné čerpat např́íklad z př́spěvku Ginnse a Barrieho (2004).

Zároveň je však možné neuzavírat ani možnost měření studijní zkušenosti na globální úrovni, které může, např́íklad u absolventů nebo také u studentů po inovacích studijních plánů a realizovaných inovacích většího rozsahu, přinést důležité podněty na úrovni větších celků.

Při práci s výsledky na úrovni vyšších celků je důležité mít na zřeteli skutečnost, že dotazník neměří „objektivní realitu“ vysokoškolské výuky, ale je zprávou o jejím vnímání studenty. Je doloženou skutečností, že výpovědi studentů souvisí nejenom s výukou jako takovou, ale i s pedagogickou kulturou a zvyklostmi v jednotlivých předmětech, oborech, s velikostí studijních skupin a s epistemickou úrovní studentů (Ramsden, 1991). Jako takové není vhodné číselné výsledky těchto percepcí porovnávat mezi odlišnými předměty, obory nebo institucemi, ale vždy v rámci blízkých a srovnatelných celků a skupin (Ramsden, 1991). Dotazník by měl sloužit především 
jako příležitost pro identifikaci oblastí, v nichž může být výuka zkvalitňována, nikoli jako nástroj pro porovnávání institucí s odlišnými obory, kulturami a podmínkami.

\section{Závěr}

Studie popisuje průběh a výsledky validace a adaptace dotazníku CEQ za účelem jeho využití pro evaluaci výuky v prostředí českého vysokého školství. Dotazník vznikl v 80. letech v Austrálii, a přestože byl vytvořen jako indikátor výkonu na institucionální úrovni a sloužil zejména pro účely vzdělávací politiky a financování, v průběhu následujících let byla věnována velká pozornost testování využitelnosti nástroje pro evaluační účely a v zahraničí se stal jedním z nejvýraznějších evaluačních nástrojů využívaných ve vysokém školství. Faktorová struktura dotazníku zůstává v našem prostředí zachována a na základě realizovaných analýz je možné jej považovat za validní a spolehlivý nástroj. Příspěvek pojmenoval několik různých způsobů jeho využití v aktuálních podmínkách českých vysokých škol a naznačil další možné úpravy a analýzy.

\section{Literatura}

Ainley, J., \& Long, M. (1994). The Course Experience survey 1992 graduates. Canberra: Australian Government Publishing Service.

Al-Harti, A. S. (2005). Distance higher education experiences of Arab Gulf students in the United States: A cultural perspective. The International Review of Research in Open and Distance Learning, 6(3), 1-14.

Beaty, E., Dall'Alba, G., \& Marton, F. (1997). The personal experience of learning in higher education: Changing views and enduring perspectives. In P. Sutherland (Ed.), Adult learning: A reader (s. 150-165). Londýn: Kogan Page.

Bell, S., Galilea, P., \& Tolouei, R. (2010). Student experience of a scenario-centred curriculum. European Journal of Engineering Education, 35(3), 235-245.

Biggs, J. (1989). Approaches to the enhancement of tertiary teaching, Higher Education Research and Development, 8, 7-25.

Biggs, J. (1993). What do inventories of students' learning processes really measure? A theoretical review and clarification. British Journal of Educational Psychology, 63, 3-19.

Cashin, W. E., \& Perrin, P. B. (1978). IDEA Technical Report No. 4. Description of IDEA Standard Form Data Base. Manhattan: Center for Faculty Evaluation and Development in Higher Education.

Chapman, K. (1996). An analysis of degree results in geography by gender. Assessment and Evaluation in Higher Education, 21(4), 293-313.

Elphinstone, L. J. (1990). The development of the Course Experience Questionnaire (unpublished M.Ed. thesis). University of Melbourne. 
Entwistle, N. J., Hanley, M., \& Hounsell, D. (1979). Identifying distinctive approaches to studying. Higher Education, 8, 365-380.

Entwistle, N. J., \& Ramsden, P. (1983). Understanding student learning. Londýn: Croom Helm.

Entwistle, N. J., \& Tait, H. (1990). Approaches to learning, evaluations of teaching and preferences for contrasting academic environments. Higher Education, 19, 169-194.

Espeland, V., \& Indrehus, O. (2003). Evaluation of students' satisfaction with nursing education in Norway. Journal of Advanced Nursing, 42(3), 226-236.

Gaff, J. F., Crombag, H., \& Chang, T. (1976). Faculty cultures and interdisciplinary studies. Journal of Higher Education, 3, 186-201.

Ginns, P., \& Barrie, S. (2004). Reliability of single-item ratings of quality in higher education: A replication. Psychological Reports, 95, 1023-1030.

Ginns, P., Prosser, M., \& Barrie, S. (2007). Students' perceptions of teaching quality in higher education: The perspective of currently enrolled students. Studies in Higher Education, 32(5), 603-615.

Grace, D., Weaven, S., Bodey, K., Ross, M., \& Weaven, K. (2012). Putting student evaluations into perspective: The Course Experience Quality and Satisfaction model (CEOS). Studies in Educational Evaluation, 38, 35-43.

Grebennikov, L., \& Skaines, I. (2009). Gender and higher education experience: A case study. Higher Education Research and Development, 28(1), 71-84.

Griffin, P., Coates, H., McInnis, C., \& James, R. (2003). The development of an extended Course Experience Questionnaire. Quality in Higher Education, 9(3), 259-266.

Harvey, A., \& Kamvounias, P. (2008). Bridging the implementation gap: A teacher-as-learner approach to teaching and learning policy. Higher Education Research and Development, 27(1), 31-41.

Juklová, K. (2019). Osobní epistemologie budoucího učitele. Predikce a podpora studijních procesů a výsledků. Praha: Grada Publishing.

Juklová, K., Chvál, M., Michek, S., \& Vondroušová, J. (2019). Studentská hodnocení výuky s využitím dotazníku CEQ: analýza zahraničních zkušeností. Pedagogická orientace, 29(3), 290-335.

Kuh, G. D. (2009). The National survey of student engagement: Conceptual and empirical foundation. New Direction for Institutional Research, 141, 5-20.

Landbeck, R., \& Mugler, F. (1994). Approaches to study and conceptions of learning of students at the USP. Suva: University of the South Pacific, Centre for the Enhancement of Learning and Teaching.

Law, D., \& Meyer, J. (2011). Relationships between Hong Kong students' perceptions of the learning environment and their learning patterns in post-secondary education. Higher Education, 62(1), 27-47.

Liu, J. C., St. John, K., \& Courtier, A. M. B. (2017). Development and validation of an assessment instrument for course experience in a general education integrated science course. Journal of Geoscience Education, 65(4), 435-454.

Lizzio, A., Wilson, K., \& Simmons, R. (2002). University students'perceptions of the learning environmnet and academic aoutcomes: Implications for theory and practice. Studies in Higher Education, 27(1), 27-51. 
Lyon, P. M., \& Hendry, G. D. (2002). The use of the Course Experience Questionnaire as a monitoring evaluation tool in a problem-based medical programme. Assessment \& Evaluation in Higher Education, 27(4), 339-352.

Maramble, K. N., et al. (2012). A cross-cultural comparison of student learning patterns in higher education. Higher Education, 64, 299-316.

Marsh, H. W. (1982). SEEQ: A reliable, valid and useful instrument for collecting students' evaluations of university teaching. British Journal of Educational Psychology, 52, 77-95.

Marton, F., \& Pang, M. F. (2006). On some neccessary conditions of learning. Journal of the Learning Sciences, 15, 193-220.

Marton, F., \& Saljö, R. (1976). On qualitative differences in learning I - outcome and process. British journal of Educational Psychology, 46, 4-11.

McInnis, C., Griffin, P., James, R., \& Coates, H. (2001). Development of the Course Experience Questionnaire (CEQ). Canberra: Department of Education, Training and Youth Affairs.

Meyer, J. H. F., \& Parsons, P. (1989). Approaches to studying and course perceptions using the Lancaster Inventory - a comparative study. Studies in Higher Education, 14, 137-263.

Michek, S., \& Maněnová, M. (2016). Hodnocení učitelů studenty na Pedagogické fakultě UHK. In J. Malach, Z. Sikorová, \& N. Sklenářová (Eds.), Vnitřní evaluace kvality výuky v terciárním vzdělávání. Ostrava: Ostravská Univerzita v Ostravě.

Perry, W. G. (1970). Forms of intellectual and ethical development in the college years: A scheme. New York: Holt, Rinehart \& Winston.

Price, L., Richardson, J. T. E., \& Jelfs, A. (2007). Face-to-face versus online tutoring support in distance education. Studies in Higher Education, 32(1), 1-20.

Ramsden, P. (1979). Student learning and perceptions of the academic environment. Higher education, 8(4), 411-427.

Ramsden, P. (1983). The Lancaster Approaches to Studying and Course Perceptions Questionnaire: Lecturer's handbook. Oxford: Educational Methods Unit, Oxford Polytechnic.

Ramsden, P. (1991). A performance indicator of teaching quality in higher education: The Course Experience Questionnaire. Studies in Higher Education, 16(2), 129-150.

Ramsden, P., \& Entwistle, N. J. (1981). Efect of academic departments on students' approaches to studying. British Journal of Educational Psychology, 51, 368-383.

Ramsden, P., Martin, E., \& Bowden, J. (1989). School environment and sixth from pupils' approaches to learning. British Journal of Educational Psychology, 59, 129-142.

Richardson, J. T. E. (1994). A British evaluation of the Course Experience Questionnaire. Studies in Higher Education, 19(1), 59.

Richardson, J. T. E, \& King, E. (1991). Gender differences in the experience of higher education: Quantitative and qualitative approaches. Educational Psychology, 11(3/4), 363-382.

Richardson, J. T. E. (2005). Instruments for obtaining student feedback: A review of the literature. Assessment \& Evaluation in Higher Education, 30(4), 387-415.

Säljö, R. (1979). Learning about learning. Higher Education, 8, 443-451.

Smith, F. (2004). It's not all about grades: Accounting for gedered degree results in Geography at Brunel University. Journal of Geography in Higher Education, 28(2), 17-178.

Sorensen, E. (2013). Implementation and student perceptions of e-assessment in a Chemical Engineering module. European Journal of Engineering Education, 38(2), 172-185.

Soukup, P. (v tisku). Pokročilá analýza dat v SPSS a AMOS. Brno: Masarykova univerzita. 
Spooren, P., Brockx, B., \& Mortlemans, D. (2013). On the validity of student evaluation of teaching: The state of the art. Review of Educational Research, 83(4), 598-642.

Steele, G., West, S., \& Simeon, D. (2003). Using a modified Course Experience Questionnaire (CEQ) to Evaluate the innovative teaching of medical communication skills. Education for Health: Change in Learning \& Practice, 16(2), 133.

Thien, L. M., \& Ong, M. Y. (2014). The applicability of course experience questionnaire for a Malaysian university context. Quality Assurance in Education: An International Perspective, 24(1), 41-55.

Trigwell, K., \& Ashwin, P. (2003). Undergraduate students' experience of learning at the University of Oxford: University of Oxford.

Trigwell, K., \& Prosser, M. (1991a). Improving the quality of student learning: The influence of learning context and student approaches to learning on learning outcomes. Higher Education, 22, 251-266.

Trigwell, K., \& Prosser, M. (1991b). Relating approaches to study and quality of learning outcomes at the course level. British Journal of Educational Psychology, 61, 265-275.

Trigwell, K., \& Prosser, M. (1996). Changing approaches to teaching: A relational perspective. Studies in Higher Education, 21(3), 275-284.

Van Rossum, E. J., \& Taylor, I. P. (duben 1987). The relationship between conceptions of learning and good teaching: A scheme of cognitive development. Paper presented at the Annual Meeting of the American Educational Research Association, Washington DC, U.S.A.

Vermunt, J., et al. (2014). The dimensionality of student learning patterns in different cultures. In D. Gilbels, V. Donche, J. T. E. Richardson, \& J. Vermunt (Eds.), Learning patterns in higher education (s. 33-55). New York: Routledge.

Wilson, K. L., Lizzio, A., \& Ramsden, P. (1997). The development, validation and application of the Course Experience Questionnaire. Studies in Higher Education, 22(1), 33.

\section{Autoři}

Mgr. Kateřina Juklová, Ph.D., Univerzita Hradec Králové, Pedagogická fakulta, Katedra pedagogiky a psychologie, Rokitanského 62, 50003 Hradec Králové, e-mail: katerina.juklova@uhk.cz

Ing. et Bc. Stanislav Michek, Ph.D., Univerzita Hradec Králové, Pedagogická fakulta, Ústav primární a preprimární edukace, Rokitanského 62, 50003 Hradec Králové, e-mail: stanislav.michek@uhk.cz

PhDr. Ing. Petr Soukup, Ph.D., Univerzita Karlova, Fakulta sociálních věd, Katedra sociologie, Smetanovo nábřeží 6, 11001 Praha 1, e-mail: soukup@fsv.cuni.cz

PhDr. Jindra Vondroušová, Ph.D., Univerzita Hradec Králové, Pedagogická fakulta, Katedra pedagogiky a psychologie, Rokitanského 62, 50003 Hradec Králové, e-mail: jindra.vondrousova@uhk.cz

Mgr. Daniela Vrabcová, Ph.D., Univerzita Hradec Králové, Pedagogická fakulta, Katedra pedagogiky a psychologie, Rokitanského 62, 50003 Hradec Králové, e-mail: daniela.vrabcova@uhk.cz 


\section{Student's Assessment of Teaching: Adaptation of the CEQ Questionnaire for the Conditions of Czech Universities}

Abstract: The aim of the paper is to introduce the course and results of validation and adaptation of the CEQ (Course Experience Questionnaire) and to discuss its applicability in the current conditions of Czech universities. The original version of the questionnaire was created in Australia in the late 1980s and is currently one of the world's most widely used tools for assessing the quality of teaching by a student in tertiary education. Given the current need of Czech universities to implement selfevaluation processes using valid and reliable tools, we consider the verification of the psychometric properties of the questionnaire and its subsequent adaptation as one of the possible solutions. The introductory part of the text outlines the context and circumstances of the origin of the Australian original, including the theoretical concepts that became its basis. The validation and adaptation process was carried out in two phases and combined a qualitative and quantitative approach. In the first round, a focus group with students was held in order to verify consistency between the concept of teaching quality of the current generation of students of the Faculty of Education and the questionnaire. Subsequently, the translated questionnaire was administered to 661 students of teaching at the Faculty of Education of the University of Hradec Králové. The obtained data were analyzed using the confirmation factor analysis method, which confirmed the original 5-factor questionnaire structure and satisfactory internal consistency of all scales. The results of the analyzes are discussed and related to the findings of foreign authors as well as to the context of opportunities and restrictions for use in the Czech environment. In the conclusion, the study limits are highlighted and other possible directions are indicated.

Keywords: questionnaire, student, quality of teaching, evaluation of teaching, validation, adaptation 


\section{Příloha: Položky s nevyšší zátěží na faktorech} (využitelné pro průběžnou plošnou evaluaci výuky na úrovni pedagoga/předmětu)

\begin{tabular}{lcc}
\hline Znění položky & $\begin{array}{c}\text { Původní } \\
\text { číslování }\end{array}$ & $\begin{array}{c}\text { Př́slušnost } \\
\text { ke škále }\end{array}$ \\
\hline $\begin{array}{l}\text { Vyučující mě v předmětu motivoval/a k tomu, abych odvedl/a co } \\
\text { nejlepší práci. }\end{array}$ & 8 & DV \\
\hline $\begin{array}{l}\text { Měl/a jsem jasnou představu o tom, kam směřuji a co se ode mě } \\
\text { v předmětu očekává. }\end{array}$ & 6 & JCS \\
\hline * Vyučující se mě ptal/a pouze na fakta. & 20 & PH \\
\hline $\begin{array}{l}\text { Většinou jsem měl dostatek času na pochopení věcí, které se } \\
\text { musím naučit. }\end{array}$ & 15 & $\mathrm{PZ}$ \\
\hline Předmět rozvinul ...... (prostor pro konkretizaci dovednosti) & & OD \\
\hline Díky předmětu se cítím jistější při....... & & OD \\
\hline Předmět zlepšil mou dovednost............ & OD \\
\hline Předmět mi pomohl rozvinout ............ & OD \\
\hline Předmět mi pomohl rozvinout schopnost ........ & OD \\
\hline Celkově jsem byl/a s výukou spokojen/a. & - \\
\hline
\end{tabular}

